\title{
Alternativas de aposentadoria
}

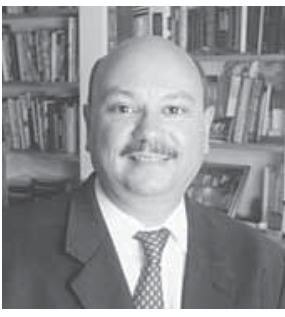

William Eid Junior

FGVEAESP

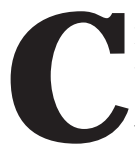

resce, no Brasil, o número de pessoas beneficiadas com o sistema de previdência privada, cujo modelo atual remonta à década de 1980 .

No entanto, uma característica comum entre todos eles é o relativo desconhecimento ou ignorância do melhor uso possível dos recursos acumulados. N esta coluna, pretendemos oferecer algumas pistas para orientar os contribuintes e beneficiários de planos de previdência privada.

A primeira oferta de produtos financeiros que visam à aposentadoria éa das seguradoras, que oferecem um leque limitado de opções, geralmente chamadas de Renda Vitalícia. Em troca do montante acumulado o indivíduo recebe mensalmente um valor fixo, que pode se estender a toda a sua sobrevida ou durante um período fixo de tempo.

Há ainda alternativas que contemplam os beneficiários, de modo que, no caso de morte do aposentado, um filho ou esposa continuam a receber o benefício ou parte dele. 0 que define o valor do benefício é uma combinação de estimativas de taxas de juros futuras com tábuas atuariais que estimam a sobrevida dos beneficiários.

O utra alternativa é a aposentadoria home made. Nesse caso, é o próprio aposentado quem gerencia seus recursos.

Imaginemos uma pessoa com 50 anos de idade e um valor acumulado igual a $\mathrm{R} \$ 1 \mathrm{mi}$ -
Ihão, e com uma estimativa de vida até os 80 anos. Um produto típico de renda vitalícia oferecerá uma rentabilidade anual izada igual a $6,20 \%$, e isso até sua morte. Em contrapartida, qual seria a rentabilidade que essa pessoa conseguiria no mercado financeiro? Essa é uma pergunta cuja resposta depende de uma série de fatores.

0 primeiro fator é a perspectiva relativa às taxas de juros. Hoje, 6,20\% é uma remuneração baixa para um montante de $R \$ 1$ milhão. Podemos facilmente atingir mais que o dobro desse valor com aplicações em CDBs e Fundos de Renda Fixa, que oferecem uma taxa de risco negligenciável. No futuro, essa taxa poderá cair, mas caberá ao investidor identificar se ela cairá abaixo dos 6,20\%, 0 que parece improvável.

O segundo fator é a disposição do investidor em administrar seus recursos. Se ele não tiver essa disposição, que implica dedicação e estudo, é melhor então deixar o encargo a terceiros, como a seguradora. Se ele tiver disposição, provavelmente vai obter melhores resultados com a aplicação e, portanto, maior conforto na aposentadoria.

Seja qual for a decisão a ser tomada, o fundamental é estudar as diferentes alternativas existentes e avaliar seus prós e contras à luz das necessidades e disposições dos indivíduos. 